\title{
Detection of Borrelia burgdorferi DNA in urine of patients with ocular Lyme borreliosis
} Uwe Pleyer, Susanne Priem, Lars Bergmann, Gerd Burmester, Christian Hartmann,
Andreas Krause
Serology is of limited value, because antibody titres are usually not detectable before 4-6 weeks after infection and may never become positive. ${ }^{5}$ Contrarily, positive Lyme serology may just indicate a past borrelial infection without proof of actual disease.

Since detection of B burgdorferi is insensitive, polymerase chain reaction (PCR) is increasingly being used to support the diagnosis. Various studies were able to demonstrate borrelial DNA in clinical specimens with a sensitivity between $20 \%$ and $100 \%$, depending on disease stage, organ manifestation, and samples analysed. ${ }^{7}$ Interestingly, urine PCR seems to be of particular value. ${ }^{9-14}$ Recently, we were able to establish an optimised PCR protocol which allows the detection of $B$ burgdorferi DNA in urine of $45 \%$ of patients with neuroborreliosis and $79 \%$ of patients with Lyme arthritis. ${ }^{9}$ Since diagnostic difficulties still exist in ocular Lyme disease and PCR has not been systematically employed so far, we aimed to evaluate its diagnostic value.

\section{Patients and methods}

We studied 256 consecutive uveitis patients from areas that are highly endemic for Lyme borreliosis. ${ }^{15}$ The diagnosis of uveitis was based on clinical characteristics according to the criteria of the IUSG. ${ }^{16}$ Detailed ophthalmic examination included biomicroscopy, three mirror contact lens examination of the eye, and fluorescein angiography in patients with retinitis or choroiditis. Patients were evaluated according to our in-house diagnostic standard for uveitis including complete history and physical examination in all patients and, depending on the clinical findings, neurological examination, $x$ ray of the chest and the sacroiliac joints, determination of HLA-B27, measurement of angiotensin converting enzyme activity, serological tests for the detection of infections with Treponema pallidum, Toxoplasma gondii, herpes simplex, herpes zoster,

Department of

Medicine,

Rheumatology and

Clinical Immunology,

Charité, Humboldt

University, Campus

Charité Mitte,

Schumannstrasse

20/21, D-10098 Berlin

$S$ Priem

G Burmester

A Krause

Correspondence to:

Dr Uwe Pleyer

uwe.pleyer@charite.de

Accepted for publication 13 December 2000

Lyme borreliosis is a systemic infectious disease caused by the tick borne spirochaete early phases it may persist causing dermatitis, less frequently $(<5 \%)$ reported $^{2}$ but may lead to persistent visual impairment. Therefore, early diagnosis and treatment are of clinical importance. ${ }^{3}$ However, the clinical diagnosis is often difficult since the majority of patients do not recall a tick bite or an erythema migrans. ${ }^{4}$

Table 1 Oligonucleotide primer sequences (from 5' to 3')

\begin{tabular}{|c|c|c|c|c|c|}
\hline Target gene & Primer & Sequence & Base no & $\begin{array}{l}\text { Amplication } \\
\text { length }(b p)\end{array}$ & $\begin{array}{l}\text { EMBL accession } \\
\text { no }\end{array}$ \\
\hline \multirow[t]{4}{*}{$\overline{\text { ospA }}$} & Outer primer 1 & ggg aat agg tct aat att agc c & $18-39$ & \multirow[t]{2}{*}{665} & \multirow[t]{4}{*}{$\mathrm{X} 66065$} \\
\hline & Outer primer 2 & Cac taa ttg tta aag tgg aag t & $660-682$ & & \\
\hline & Nested primer 1 & Gca aaa tgt tag cag cct tga $t$ & $54-75$ & \multirow[t]{2}{*}{392} & \\
\hline & Nested primer 2 & Ctg tgt att caa gtc tgg ttc c & $423-444$ & & \\
\hline \multirow[t]{4}{*}{ p66 } & Outer primer 1 & cga aga tac taa atc tgt & $9-26$ & \multirow[t]{2}{*}{371} & \multirow[t]{4}{*}{ M58429 } \\
\hline & Outer primer 2 & gat caa ata ttt cag ctt & $362-379$ & & \\
\hline & Nested primer 1 & tgc aga aac acc ttt tga at & $30-49$ & \multirow[t]{2}{*}{236} & \\
\hline & Nested primer 2 & aat cag tcc cca ttt gca & $671-690$ & & \\
\hline \multirow[t]{2}{*}{$\mathrm{PDH}$} & primer 1 & ggt atg gat gag gag ctg ga & $142-161$ & \multirow[t]{2}{*}{185} & \multirow[t]{2}{*}{ J03576 } \\
\hline & primer 2 & cag ccc tcg act aac ctt gt & $218-237$ & & \\
\hline
\end{tabular}


Table 2 Clinical data of patients with ocular Lyme borreliosis

\begin{tabular}{|c|c|c|c|c|c|c|c|}
\hline $\begin{array}{l}\text { Patient, initials, } \\
\text { age (years), sex }\end{array}$ & Ocular manifestation & Systemic symptoms & $\begin{array}{l}\text { Tick bite } \\
\text { Erythema } \\
\text { migrans }\end{array}$ & $\begin{array}{l}\text { Steroid } \\
\text { treatment } \\
\text { before dx. }\end{array}$ & $\begin{array}{l}\text { Treatment } \\
\text { treatment-response }\end{array}$ & \multicolumn{2}{|c|}{$\begin{array}{l}\text { Visual acuity } \\
\text { before/after treatment }\end{array}$} \\
\hline $\begin{array}{l}1 \mathrm{RK} \\
48, \mathrm{M}\end{array}$ & $\begin{array}{l}\text { Bilateral uveitis posterior }(>10 \\
\text { years), secondary (steroid) } \\
\text { glaucoma, relapse }\end{array}$ & Arthritis, myalgia & + & + & $\begin{array}{l}2 \text { weeks ceftriaxone IV, } \\
4 \text { weeks doxycycline PO } \\
\text { recurrence -> } \\
4 \text { weeks doxycycline PO } \\
\text { slow improvement }\end{array}$ & $\begin{array}{l}\text { RE: } 20 / 32 \\
\text { LE: } 20 / 40 \\
\text { RE: } 20 / 25 \\
\text { LE: } 20 / 25\end{array}$ & $\begin{array}{l}20 / 20 \\
20 / 25 \\
20 / 20 \\
20 / 25\end{array}$ \\
\hline $\begin{array}{l}2 \mathrm{RHF} \\
54, \mathrm{~F}\end{array}$ & $\begin{array}{l}\text { Bilateral uveitis posterior, }(>3 \\
\text { years), relapse }\end{array}$ & Arthritis, fatigue & + & + & $\begin{array}{l}2 \text { weeks ceftriaxone IV, } \\
4 \text { weeks doxycycline PO } \\
\text { recurrence -> } \\
4 \text { weeks. Minocycline } \\
\text { PO } \\
\text { slow improvement }\end{array}$ & $\begin{array}{l}\text { RE: } 20 / 125 \\
\text { LE: } 20 / 80 \\
\text { RE: } 20 / 80 \\
\text { LE: } 20 / 80\end{array}$ & $\begin{array}{l}20 / 50 \\
20 / 50 \\
20 / 50 \\
20 / 32\end{array}$ \\
\hline $\begin{array}{l}3 \mathrm{SR} \\
59, \mathrm{~F}\end{array}$ & $\begin{array}{l}\text { Bilateral uveitis intermedia, }(>5 \\
\text { years) }\end{array}$ & Arthritis & + & - & $\begin{array}{l}2 \text { weeks ceftriaxone IV, } \\
4 \text { weeks doxycycline PO }\end{array}$ & $\begin{array}{l}\text { RE: } 20 / 25 \\
\text { LE: } 20 / 25\end{array}$ & $\begin{array}{l}20 / 20 \\
20 / 25\end{array}$ \\
\hline $\begin{array}{l}4 \mathrm{UN} \\
53, \mathrm{~F}\end{array}$ & $\begin{array}{l}\text { Bilateral uveitis posterior }(>3 \\
\text { years) }\end{array}$ & $\begin{array}{l}\text { Arthritis, peripheral } \\
\text { neuropathy }\end{array}$ & + & + & $\begin{array}{l}3 \text { weeks clindamycin } \\
\text { PO, } \\
2 \text { weeks ceftriaxone IV } \\
\text { slow improvement }\end{array}$ & $\begin{array}{l}\text { RE: } 20 / 32 \\
\text { LE: } 20 / 50\end{array}$ & $\begin{array}{l}20 / 25 \\
20 / 32\end{array}$ \\
\hline $\begin{array}{l}5 \mathrm{FH} \\
37, \mathrm{M}\end{array}$ & Bilateral uveitis posterior & Hepatitis & + & + & $\begin{array}{l}3 \text { weeks ceftriaxone IV, } \\
4 \text { weeks doxycycline PO } \\
\text { slow improvement }\end{array}$ & $\begin{array}{l}\text { RE: } 20 / 32 \\
\text { LE: } 20 / 32\end{array}$ & $\begin{array}{l}20 / 20 \\
20 / 20\end{array}$ \\
\hline $\begin{array}{l}6 \mathrm{KE} \\
76, \mathrm{~F}\end{array}$ & Bilateral uveitis anterior & Headache & + & + & 4 weeks doxycycline PO & $\begin{array}{l}\text { RE: } 20 / 64 \\
\text { LE: } 20 / 64\end{array}$ & $\begin{array}{l}20 / 50 \\
20 / 32\end{array}$ \\
\hline
\end{tabular}

IV = intravenous; $\mathrm{PO}=$ by mouth.

human immunodeficiency virus, Epstein-Barr virus, and cytomegalovirus were performed. Six selected patients with clinical evidence for Lyme borreliosis were enrolled in the study. All patients reported to have had a tick bite and an erythema migrans and complained about constitutional symptoms. Five patients had arthralgias and one patient suffered from headache and fatigue. Thirty patients with various forms of uveitis not related to Lyme borreliosis served as controls.

Lyme serology was carried out using full antigen ELISA (Seramun Diagnostics, Dolgenbrod, Germany). ${ }^{9}$ Western blotting (DPC Biermann, Bad Nauheim, Germany) was done in patients with positive or indeterminate ELISA results and in patients with clinical symptoms suggestive of Lyme borreliosis but negative ELISA. Nested PCR was performed

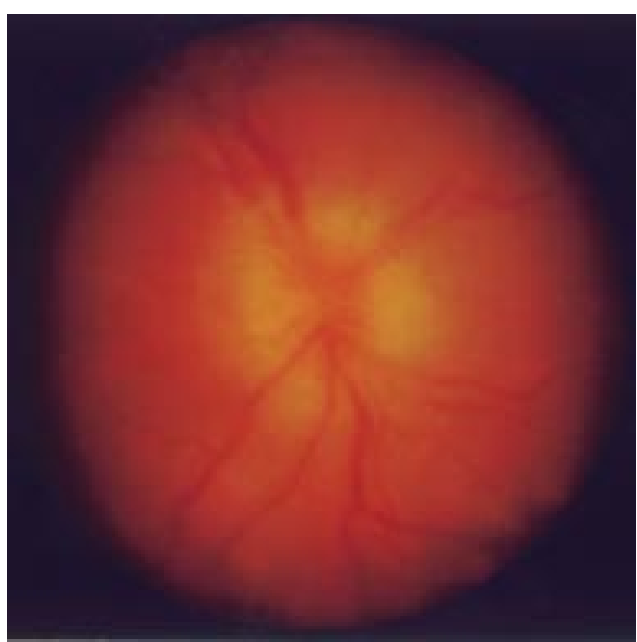

Figure 1 Fundus photograph. Patient 1 presenting with bilateral posterior uveitis, arthritis, and myalgia. Left eye at initial presentation (VA 20/40) with optic disc swelling, choroiditis, and vitritis. Seroblots were positive for immunoglobulin $G$ and B burgdorferi DNA (p66) was detectable in urine of this patient. as described previously ${ }^{9}$ using two primer sets (TIB Molbiol, Berlin, Germany) targeting the plasmid located $\operatorname{sp} A$ gene (ospA primer) and a chromosomal gene encoding a $66 \mathrm{kD}$ protein ( $p 66$ primer) (Table 1 ).

\section{Results}

The median duration of ocular disease was 6 months and even exceeded 3 years in four patients (Table 2). In all patients uveitis was present bilaterally, classified as posterior uveitis in four patients, two patients each showed perivasculitis and choroidal lesions (Figs 1 and 2). Anterior uveitis and intermediate uveitis were diagnosed once. In all patients extraocular manifestations of Lyme borreliosis could be observed including arthritis $(n=4)$, cranial nerve palsy, peripheral neuropathy $(n=1)$, and

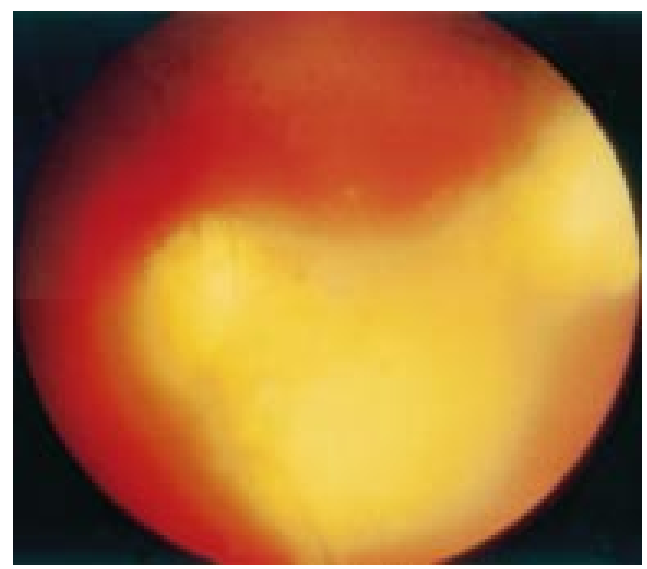

Figure 2 Patient 2 presenting with recurrent bilateral posterior uveitis and arthritis. Left eye at initial presentation (VA 20/80) with papillitis, optic disc swelling, and multiple choroidal lesions. A positive Lyme ELISA for $\operatorname{Ig} G$ and western blots for IgM and IgG were detected. Urine PCR disclosed B burgdorferi DNA (ospA) that became negative following the initial treatment course. She developed recurrent uveitis, became PCR positive again during relapse of inflammation and eventually became stable after a second treatment course. 
Table 3 Laboratory findings of patients with ocular Lyme borreliosis

\begin{tabular}{|c|c|c|c|c|c|}
\hline \multirow{3}{*}{$\begin{array}{l}\begin{array}{l}\text { Patient, age } \\
\text { (years), sex }\end{array} \\
1 \mathrm{RK} \\
48, \mathrm{M}\end{array}$} & \multirow{2}{*}{$\begin{array}{l}\text { Lyme serology } \\
\text { ELISA } \\
\text { IgM negative }\end{array}$} & \multicolumn{2}{|c|}{ Lyme seroblot $(k D a)$} & \multirow{2}{*}{$\begin{array}{l}\text { Urine PCR before } \\
\text { treatment }\end{array}$} & \multirow{2}{*}{$\begin{array}{l}\text { Urine PCR after treatment } \\
\text { negative }\end{array}$} \\
\hline & & $\operatorname{IgM}$ & ND & & \\
\hline & IgG negative & IgG & $66,62,41,37,18$ & & \\
\hline $2 \mathrm{RHF}$ & IgM negative & IgM & $41,39,31,21$ & positive for ospA & negative, after recurrence \\
\hline $54, \mathrm{~F}$ & IgG positive & IgG & $72,62,41,29,18$ & & positive again for ospA \\
\hline $3 \mathrm{SR}$ & IgM negative & IgM & ND & positive for $\mathrm{p} 66$ & negative \\
\hline $59, \mathrm{~F}$ & IgG positive & IgG & $93,72,60,41,39,34,30,25,18$ & & \\
\hline $4 \mathrm{UN}$ & IgM negative & IgM & ND & positive for ospA & negative \\
\hline $53, \mathrm{~F}$ & IgG positive & IgG & $(93), 72,66,62,60,48,34,31,29,18$ & & \\
\hline $5 \mathrm{FH}$ & IgM negative & $\operatorname{IgM}$ & ND & positive for p66 & negative \\
\hline $37, M$ & IgG negative & IgG & $66,60,41,39,31$ & & \\
\hline $6 \mathrm{KE}$ & IgM negative & $\operatorname{IgM}$ & ND & positive for $\mathrm{p} 66$ & negative \\
\hline $76, \mathrm{~F}$ & IgG positive & IgG & $\begin{array}{l}66,62,60,41,39,37,34,29,28,21, \\
18\end{array}$ & & \\
\hline
\end{tabular}

$\mathrm{ND}=$ not done.

hepatitis $(n=1)$. ELISA was positive in four patients while two patients were repeatedly seronegative. However, western blots were positive $^{17}$ in all patients (Table 3). In the control group only $2 / 30$ patients $(7 \%)$ showed positive ELISA and/or western blot results.

$B$ burgdorferi PCR was positive in all urine samples from patients with ocular Lyme borreliosis. In contrast, in none of the 30 urine specimens from controls could $B$ burgdorferi DNA be detected. After antibiotic treatment PCR became negative in all patients. Marked improvement of the ocular manifestation was seen in our patients with anterior uveitis, and a more protracted response was observed in all individuals with posterior manifestation. Uveitis relapsed in two of these cases. Both had received systemic corticosteroids which may have contributed to treatment failure. One patient temporarily became PCR positive again during relapse. After a second treatment course, a stable reduction of intraocular inflammation was achieved.

\section{Discussion}

The results of the present investigation showed that in six uveitis patients with a history and clinical signs of Lyme disease $B$ burgdorferi DNA could be detected in urine samples. Since we only analysed highly selected patients and not all patients with findings compatible with Lyme borreliosis our results do not allow us to calculate the sensitivity of urine PCR in the diagnosis of Lyme uveitis. However, PCR was negative in all 30 patients with none-Lyme uveitis giving a specificity of $100 \%$.

Although a positive PCR does not prove an infection with viable organisms, the positive results in our patients with clinical manifestations that resolved after antibiotic therapy strongly suggest spirochaetal persistence. In view of the current discussion about persistent infection versus infection induced immunopathology as the main mechanisms of chronic Lyme borreliosis our results point towards a direct infectious cause of ocular Lyme disease. ${ }^{18}$ In one patient affected by a recurrent episode of bilateral chorioretinitis, urine PCR became positive again during relapse. The second treatment course not only improved the clinical manifestation of uveitis, but also led to a negative urine PCR on repeated tests. This may indicate that PCR might be of value in following the infectious course of the disease. Adequate negative controls were run with each test to rule out false positive results. In addition, we already proved by sequencing of the PCR products that with our protocol $B$ burgdorferi DNA is amplified exclusively.

Serological analysis in our PCR positive patients revealed that only four patients had a positive Lyme serology as determined by ELISA. In contrast, IgG immunoblots were positive in all six patients. It is well known that serological reactions may vary considerably and that a negative serology does not exclude the infection. ${ }^{620}$ Possible explanations for this phenomenon include the invasion of spirochaetes into immunologically privileged sites. $^{2021}$ Several investigators have reported impaired immune responses in uveitis patients with confirmed diagnosis of Lyme borreliosis. $^{321}$ Moreover, most of our patients had received immunosuppressive therapy such as corticosteroids that probably led to negative or weak immune response ${ }^{9}$ and delayed diagnosis even for years.

Taken together, Lyme borreliosis has to be considered as a (rare) cause of intraocular inflammation even with negative ELISA findings. Additional laboratory tests, in particular immunoblots, are indicated in suspicious individuals - for example, in patients with extraocular manifestations compatible with Lyme disease. Nested PCR appears to be a valuable tool to identify patients with long standing disease. Moreover, PCR may also help to monitor the efficacy of anti-infectious therapy in patients with intraocular borrelial infections. However, the clinical value of this diagnostic tool, especially its sensitivity, still needs to be determined in subsequent studies.

Supported by DFG (Pl 150/10-1), (Kr 997/2-1), and BMBF (01 KI 9503).

1 Van Dam A, Kuiper PH, Vos K, et al. Different genospecies
of Borrelia burgdorferi are associated with distinct clinical
manifestations of Lyme borreliosis. Clin Infect Dis
1993;17:708-17.
2 Rosenbaum JT, Rahn DW. Prevalence of Lyme disease
among patients with uveitis. Am f Ophthalmol 1991;112:
462-3. 
3 Karma A, Seppälä I, Mikkilä $\mathrm{H}$, et al. Diagnosis and clinical characteristics of ocular Lyme borreliosis. Am f Ophthalmol

4 Rahn DW, Malawista SE. Lyme disease. Recommendations for diagnosis and treatment. Ann Intern Med 1991;114 $472-81$.

5 Krause A, Burmester GR, Rensing A, et al. Cellular immune reactivity to recombinant OspA and flagellin from Borrelia burgdorferi in patients with Lyme borreliosis. Complexity of humoral and cellular immune responses. $\mathcal{F}$ Clin Invest 1992;90:1077-84.

6 Dattwyler RJ, Volkman DJ, Luft BJ, et al. Dissociation of burgdorferi. N Engl F Med 1988;319:1441-6.

7 Jaulhac B, Nicolini P, Piemont Y, et al. Detection of Borrelia burgdorferi in cerebrospinal fluid of patients with Lyme borreliosis. N Engl f Med 1991;324:1440-5.

8 Mouritsen CL, Wittwe CT, Litwin CM, et al. Polymerase chain reaction detection of Lyme disease. Correlation with clinical manifestations and serologic responses. Am f Clin Pathol 1996;105:647-54.

9 Priem S, Rittig MG, Kamradt T, et al. An optimized PCR leads to rapid and highly sensitive detection of Borrelia burgdorferi in patients with Lyme borreliosis. $\mathcal{F}$ Clin Microbiol 1997;35:685-90.

10 Schwan TG. The urinary bladder, a consistent source of Borrelia burgdorferi in experimentally infected whitefooted mice (permyscus leucopus). I Clin Microbiol 1988;26:893-4

11 Magnarelli LA, Anderson JF, Stafford III KC. Detection of Borrelia burgdorferi in urine of Peromyscus leucopus by inhibition enzyme-linked immunosorbent assay. 7 Clin Microbiol 1994;32:777-82

12 Lebech AM, Hansen K. Detection of Borrelia burgdorferi DNA in urine samples and cerebrospinal fluid samples from patients with early and late lyme borreliosis by polymerase chain reaction. 7 Clin Microbiol 1992;30:164653 .

13 McGuire BS, Chandler FW, Felz MW, et al. Detection of Borrelia burgdorferi in human blood and urine using the polymerase chain reaction. Pathobiology 1992;60:163-7.

14 Schmidt BL. PCR in laboratory diagnosis of human Borrelia burgdorferi infections. Clin Microbiol Rev 1997;10:185201.

15 Kolmel HW, Neumann P, Schneider T, et al. Prevalence of antibodies to Borrelia burgdorferi in serum and cerebrospinal fluid samples from patients with neurological disorders in Berlin. Int f Med Microbiol Virol Parasitol Infect Dis 1992; in Berlin. Int

16 Bloch-Michel E, Nussenblatt RB. International uveitis study group recommendations for the evaluation of intraocular inflammatory disease. Am f Ophthalmol 1987; 103:234-5.

17 Hauser U, Lehnert G, Lobentanzer R, et al. Interpretation criteriae for standardized western blots for three european species of Borrelia burgdorferi sensu latu. 7 Clin Microbiol 1997;35:1433-44.

18 Gross DM, Forsthuber T, Tary-Lehmann M, et al. Identification of LFA-1 as a candidate autoantigen in treatmentresistant Lyme arthritis. Science 1998;281:703-6.

19 Krause A, Brade V, Schoerner C, et al. T cell proliferation induced by Borrelia burgdorferi in patients with lyme borreliosis. Arthritis Rheum 1991;34:393-402.

20 Häupl T, Hahn G, Ritting M, et al. Persistence of Borrelia burgdorferi in ligamentous tissue from a patient with chronic lyme borreliosis. Arthritis Rheum 1993;36:1621-6.

21 Preac-Mursic V, Pfister HW, Spiegel H, et al. First isolation of Borrelial burgdorferi from iris biopsy. 7 Clin NeuroOphthalmol 1993;13:155-61. 